\title{
Irregularities in Czech Integrated Periodic Timetable
}

\author{
Michal Drábek ${ }^{1 *}$ \\ ${ }^{1}$ Czech Technical University in Prague, Faculty of Transportation Sciences, Department of Logistics and Management of Transport, \\ Horská 3, 12803 Praha 2, Czech Republic
}

\begin{abstract}
The aim of this paper is categorization of various irregularities in Integrated Periodic Timetable (IPT), according to their impact on passengers. For instance, minor deviations in departure minutes can cause almost zero impact, provided that all periodic transfer connections are ensured for each service. On the other hand, skipping of a periodic service at off-peak hours can considerably lengthen some passenger transport chains. Chosen categories of irregularities are illustrated by examples from 2017/2018 Czech railway timetable.
\end{abstract}

\section{Integrated Periodic Timetable (IPT)}

Contrary to periodic timetable, as used, for instance, in urban public transport, IPT requires unified service period and unified symmetry time among all involved public transport lines.

Unified period means that there is some basic network period $t_{\mathrm{p}, \mathrm{b}}$ (e.g. $60 \mathrm{~min}$ ), and any other period $t_{\mathrm{p}, \mathrm{i}}$ has to fulfil following equation

$$
t_{\mathrm{p}, \mathrm{i}}=2^{k} \cdot t_{\mathrm{p}, \mathrm{b}}
$$

where $k$ is an integer.

If a 60 min basic period is chosen, periods of 120,30 and 15 min can be used as well.

Unified timetable symmetry is necessary for symmetrical transfer connections within both directions. Symmetry time of a public transport line occurs when two services in opposite directions meet each other. In European railway network, symmetry time in (or slightly before) the minute 00 has been established as a rule. It is desirable to design an IPT-node in a station where two or more public transport lines intersect. In an ideal IPT-node, all services arrive before the minute 00 , and all services depart after the minute 00 . For the sake of maintaining unified zero symmetry, each public transport line should keep following rule. If the service from the station A arrives $x$ minutes before 00 , the service in opposite direction (to A) should depart $x$ minutes after 00 . Thus, the first arrivial corresponds to the last departure back (within the particular public transport line and direction).

Unified basic period, unified symmetry time and system of IPT-nodes imply some mathematical preconditions - arc and circle equations [1-3].

If two services (with 60 min period) depart from two neighbouring «zero» IPT-nodes, towards each other, they meet each other in another symmetry time - the minute 30 . If they stop, another IPT-node in the minute
30 can be designed there. If generalized to any basic period, arc equation comes out, formulated as follows:

$$
t_{\mathrm{T}, \mathrm{A} \leftrightarrow \mathrm{B}}=(n / 2) \cdot t_{\mathrm{p}}
$$

where $t_{\mathrm{T}, \mathrm{A} \leftrightarrow \mathrm{B}}$ is travel time between IPT-nodes $A$ and $B$, including both half of dwell time in node $A$ and half of dwell time in node $\mathrm{B}$, and $n$ is natural number. Scheduled travel time between two IPT-nodes, rounded up to fulfil the arc equation, is called system travel time.

In any IPT, there are two disjunct groups of IPTnodes (e.g. for $60 \mathrm{~min}$ period and zero symetry, it is group of nodes around the minute 00, and group of nodes around the minute 30 ). IPT works properly provided that all services arrive into any IPT-node before the same symmetry time and depart thereafter. If the symmetry time is the minute 00 , any arrival before the minute 30 leads to unacceptable transfer time between services. Thus, even stronger precondition than arc equation has to be maintained - formulated as cycle equation:

$$
\forall(\mathrm{A}, m): t_{\mathrm{T}, \mathrm{A} \leftrightarrow \mathrm{A}, \mathrm{m}}=n \cdot t_{\mathrm{p}}
$$

where $t_{\mathrm{T}, \mathrm{A} \leftrightarrow \mathrm{A}, \mathrm{m}}$ is travel time along $m$-th cycle from node $A$ into node $A$, including at least 2 another IPT-nodes and dwell time in $A$, and $m, n$ are natural numbers.

All preconditions for proper working of IPT for passengers are summarized below:

- Exact basic period, or its $2^{k}$-multiples (implies unified travel time for each section).

- Unified symmetry time (implies equal travel time there and back).

- Arc equation (system travel time).

- Circle equation (two disjunct groups of IPT-nodes).

* Corresponding author: xdrabek@,fd.cvut.cz 


\section{Irregularities with network impact}

Network impact means that at least one periodic transfer connection is broken due to irregularity in IPT. Either a periodic service is skipped, or the minimum transfer time cannot be kept due to late scheduled arrival of particular service.

Skipping of periodic connections at off-peak times is motivated by (at least variable) cost saving for public service orderer. However, two or more skipped services in «unlucky» time sequence can considerably lengthen public transport chain. For instance, a passenger travelling from Česká Lípa to Náchod has to transfer twice - in Nymburk and Hradec Králové. Fast train lines operate in 120 min period. In the ideal case, the travel time between two cities by train lasts about 3.5 hours. However, at weekends there are some services skipped. As a result, in 2017 Czech timetable, from 7 daily connections, four ones lasted 1 hour longer, due to skipped services on one or two involved public transport lines (R22, R10 [4] and a regional line). All three lines contained some skipped services at weekends. In other words, only three connections daily offered travel time, planned by public service orderers [5].

One regional public service orderer, Liberec Region (Liberecký kraj), via its subsidiary KORID LK and in cooperation with neighbouring Central Bohemia Region (Středočeský kraj), has patched a pair of skipped fast train services of the R22 line [4] around noon by a pair of regional train services 6022 and 6009 between Rumburk and Mladá Boleslav (railway lines 081 and 080). It sounds like irony of fate, since both fast and regional trains on this corridor are operated by stateowned carrier Czech Railways (České dráhy). But one orderer is forced to fix a hole that another orderer was unable to fix himself - both by one railway carrier. Another interesting fact is that this pair of train services serves between Česká Lípa and Bakov nad Jizerou 7 stops more (mostly on request) than the fast train. Nevertheless, interposition into exactly periodic times has been kept - likely thanks to off-peak time and thus low passenger demand. Further, from Mladá Boleslav to Kolín, the pair of fast train services is skipped without any patching [6].

The longer waiting time has considerable impact on public transport quality, as estimated for instance by Gašparík et al. [7].

The officially declared cause of skipped periodic services is lack of available funding [8]. The most likely reason, however, is the fixed amount of compensation per train-kilometre in public service contracts (which comes out from negotiated sum of train-kilometres and total amount of compensation). The vast majority of sum of publicly ordered train-kilometres in the Czech Republic is operated by Czech Railways. Although Czech Railways very often can profit from more efficient use of their rolling stock thanks to networkwide operation, they insist on fixed price of trainkilometre even if this would cost no extra trainset.

An interesting case is shift of periodic service about half period. The reason may be diluting of the offer during off-peak time (especially before noon or during late evening - see Figure 1), or plenty of timetabling constraints. The other variant occurs on international line of express trains between Poland and Vienna. One pair of services terminates in Budapest instead. In the Czech Republic, this line is marked as Ex4 [4]. Its services keep periodic times, but their period varies. Either it is 120, or 180 or even 240 minutes [6].

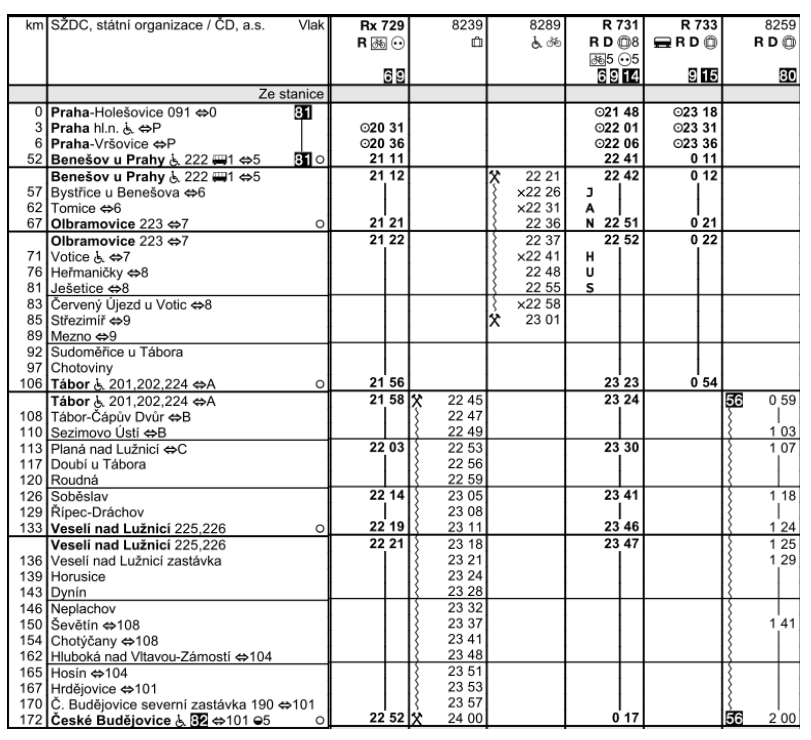

Fig. 1. Cut-out from 2017/2018 timetable Praha - České Budějovice. During late evening, 90 min period is used [6].

Another case is an "almost-transfer" when both services operate, but minimum transfer time cannot be kept. In this category, few minutes do not matter, because arrival time of the service is completely different - mostly intentionally.

The first variant, more common at the morning peak, is a service adjusted to start of school tuition, or shift by large employer. This irregularity is difficult to cope in more sparsely populated areas, since an extra trainset for extra «periodic» connection cannot be justified by sufficient passenger demand.

The second variant occurs if system travel time cannot be fulfilled due to infrastructure constraints - or due to number of stops.

In the Czech Republic, there is another very widespread timetable irregularity - non-systematic differences in days of operation of the train services. This issue is so complex that it cannot be fully described in this paper. One illustrative example is the R26 fast train line Praha - Beroun - Písek - České Budějovice [4], regarded by the orderer as «the least evil» whenever some services have to be reduced for financial reasons [8]. Thus, some services run for instance only on Mondays or on Fridays. On the other hand, South Bohemian Region (Jihočeský kraj) has ordered fast trains between České Budějovice and Písek město when the R26 fast trains do not run. However, this order is not ideal. For instance, the pair of 633 and 634 fast trains serve the station Písek město on workdays, but without Fridays, since fast train to and from Prague runs on Fridays from the station Písek through another line see timetables of railway lines 200 and 190 [9]. 


\section{Irregularities with no network impact}

No network impact means that these irregularities do not break periodic transfer connections off. They can be divided as follows:

- Minor irregularities that enable maintenance of minimum transfer time.

- Local irregularities (periodic arrival and departure times in transfer nodes are maintained).

- Major irregularities.

The first group is represented by few minutes' deviation in periodic arrival and departure times in the node stations. If the scheduled transfer time is shortened, the buffer time can be exhausted this way, so such connection can lower stability of the traffic. In some cases, buffer time is added to absorb the irregularity and keep it limited to a particular section. An interesting example is local shift of departure and arrival times of the R18 long-distance line between Přerov and Staré Město u Uherského Hradiště [4] (railway line 330). This shift is driven by fluctuating period of Ex4 line, mentioned in the chapter above. If the train of Ex4 runs, the R18 train departs from Přerov 3 min earlier to avoid timetabling conflict. The buffer time as long as 3 or 4 min is added in Staré Město where electric locomotive is changed to the diesel one. If there runs no Ex4 train, the R18 train waits in Přrov and arrives in Staré Město to dwell just as long for the locomotive changing. This irregularity occurs in both directions, but the difference in departure times backwards from Staré Město towards Přrerov is only $1 \mathrm{~min}$ [6].

In extreme cases, hold-up for extra stoppings is absorbed by buffer time and low demand thanks to offpeak time (see the "patching" regional trains mentioned in rhe chapter above). [10]

The second group is represented by terminus that differs from the periodic pattern or by passing through some periodically served stops.

The third group is represented by extra peak services that do not replace periodic services.

Figure 2 displays several types of irregularities that are built in rather periodic timetable.

The first, major irregularity, is termination of 7452 train in Stod. Thus, the rest of line to Domažlice město is not served $100 \%$ hourly.

The second, middle irregularity, is infrastructuredriven waiting of regional trains in Staňkov station (in even hours only) to let run the express train in the opposite direction. [11] Thus, precise interposition into hourly service is no more possible between Staňkov and Domažlice město. In the opposite direction, waiting time is shorter, probably because of preference of morning commuting to afternoon travelling back. This irregularity affects timetable symmetry between Staňkov and Domažlice město.

The third, minor irregularity, is scheduled running of 7416 train between Domažlice and Domažlice město at weekends only. The reason may be rolling stock utilization at the afternoon peak (fast turn-around in Domažlice).
The fourth, minor irregularity, is skipping of stop in Dolní Kamenice for several trains (sometimes the train stop there at weekends).

The fifth, minor irregularity is a slight difference in scheduled runtimes of 7410,7412 and 7416 trains. The reason might be different dynamic traction characteristic of different trainsets $[6,9]$.

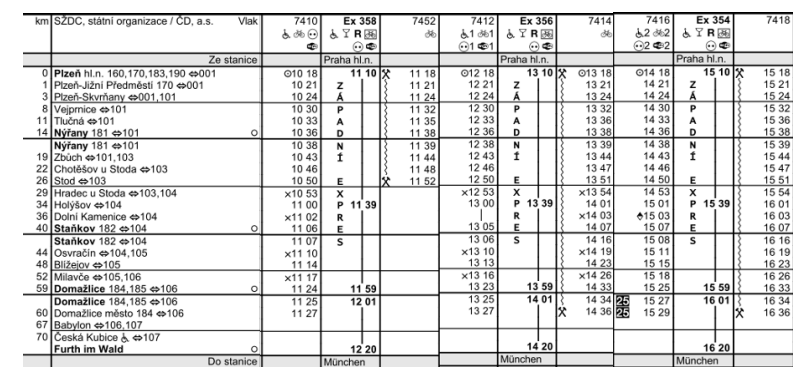

Fig. 2. Cut-out from 2017/2018 timetable Plzeň - Furth im Wald with several types of minor and middle irregularities [6].

\section{Recommendations for reduction of network impact}

The author proposes three, rather soft, criteria for the decision on seriousness of network impact of irregularity in IPT:

- Daytime.

- Significance within railway network.

- Complexity of transfer connections.

\subsection{Daytime}

The most serious irregularities in IPT, like major shift of departure and arrival times of the service, are acceptable at the morning peak, preferably in the direction with larger passenger flows, provided that

- There is more passengers profiting from the irregularity than losing due to it (e.g. they may lose the transfer connection).

- Otherwise there would be an extra trainset needed and the amount of passenger flows does not justify it.

Another times with acceptable major irregularities are «edge» times - early morning or late evening. The demand is comparably low and trainsets may depart from depots or arrive towards them. However, as much transfer connections as possible should be kept. So the irregularity should spread outside the transfer node if possible.

\subsection{Significance within railway network}

The author recommends following criteria for significance:

- Significance of settlement served.

- Temporal proximity to agglomeration centre.

- Centrality within railway network.

The sense of the first criterion is evident.

The second criterion is significant in proportion to size and transport attractiveness of the agglomeration. 
For instance, 60 min travel time to Český Těšín is much less significant than 60 min travel time to Brno.

The third criterion is linked to railway capacity utilization. The more central (i.e. more utilized) element of railway network is affected by the irregularity, the larger impact on another periodic railway services. Thus, for instance, irregularity between Kolín and Pardubice has much larger impact that irregularity between Břeclav and Znojmo.

\subsection{Complexity of transfer connections}

The author recommends following criteria for complexity of transfer connections:

- Number of node stations with transfer connections along the route of public transport line.

- Amount of the highest appeared number of transfer connections in one station.

\section{Conclusion}

There is clear evidence that IPT has increased quality of passenger railway and demand for it [2]. However, its inconsistent application by many public service orderers, combined with low emphasis on efficient rolling stock utilization and on potential synergistic effects between various orders by Czech Railways has led to plenty of irregularities that undermine the very nature of ITF to offer periodic, lucid, uncluttered public transport service to passengers.

Of course, the number of passengers equipped with mobile internet is steadily growing. These passengers can find their timetable online anytime. Nevertheless, if they can only memorize simple information, such as «departure in the minute 42 , and at peak times in the minute 12 in addition», the public transport would be much more attractive and user-friendly.

The research and publishing of this paper was supported by Zéta Programme of The Technology Agency of the Czech Republic (TAČR), as a part of the research project TJ01000162 "Synergy in Railway Public Transport Line Planning Improvement of Efficiency of Spatial Public Railway Transport Service" - co-financed by CTU in Prague. Actual (so far unpublished) version of the project research report [10] was cited in this paper. The author hereby acknowledges the funding sponsors.

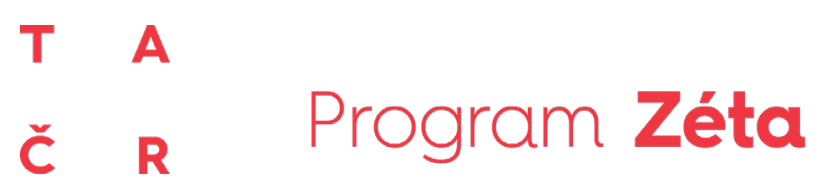

\section{References}

1. Forschungsgesellschaft für Straßen- und Verkehrswesen, e. V. Merkblatt zum Integralen Taktfahrplan (FGSV-Verlag GmbH, Cologne, Germany, 2001, pp. 18-20)

2. V. Borza, V. Janoš, I. Neumann, R. Roth, $H$. Jacolin, Eastern European railways in transition: Nineteenth to twenty-first centuries. 327-342 (2013)

3. V. Janoš et al., Lecture in the subject Transport Technology and Logistics. (2017)

4. SŽDC, s.o Portál provozováni dráhy (2017). Available online: http://provoz.szdc.cz/PORTAL/Show.aspx?path=/D ata/Mapy/linky_dalkove_dopravy.pdf

5. R. Papež, ŽelPage, Oct 19, (2016) Available online: http://www.zelpage.cz/zpravy/9697?lang=cs\&oddil $=6 \#$ komentare

6. SŽDC, s.o., Jízdní řády (platné od 10. 6. 2018), (2017). Available online: https://www.szdc.cz/provozovani-drahy/kniznijizdni-rady.html

7. J. Gašparík, V. L'uptak, P. Mesko, Proceedings of the 3rd International Conference on Traffic and transportation Engineering (ICTTE), 388-392 (2016), WOS 000391016300055)

8. J. Klimková, J. Čamaj, J. Gašparík. Transport means 2016 : proceedings of the 20th international scientific conference. 891-896. (2016)

9. Ministerstvo dopravy, Plán dopravní obsluhy vlaky celostátni dopravy. (2017). Available online : https:/www.mdcr.cz/getattachment/Dokumenty/Ver ejna-doprava/Financni-ucast-statu/Plan-dopravniobsluhy-uzemi-vlaky-celostatni-dopra/Plandopravni-obsluhy-uzemi-2017-2021.pdf.aspx

10. SŽDC, s.o., Sbirka služebních pomi̊cek pro jizdni rád 2017/18 (2017) - Unpublished

11. M. Drábek et al., Analytická část. Zpráva o dosažených výsledcích projektu TJ0100162 řš́eného s finanční podporou TA $\check{C} R$. Research report in progress, to be finished in 2019, (2018) Unpublished 